\title{
THE USE OF THEME-BASED APPROACH IN TEACHING YOUNG LEARNERS' VOCABULARY OF ENGLISH CLUB AT NUR HIDAYAH ISLAMIC ELEMENTARY SCHOOL
}

\author{
Cahyaning Fristiara, Rani Rahmawati \\ tiarafristie@student.uns.ac.id; ranirahmawati722@gmail.com
}

Universitas Sebelas Maret

\begin{abstract}
The use of appropriate technique in order to achieve the goal of teaching and learning English takes the important role in English language teaching. Young learner as the basic of education is one of objects in education. It needs an appropriate approach to teaching English for young learners. One of appropriate approaches is theme-based approach. It is an approach of organizing teaching around themes or topics making it possible to integrate instruction across core areas such as listening, speaking, reading, and writing. This study aims to find out the use of theme-based approach to teach English vocabulary for young learners in English club of Nur Hidayah Elementary Islamic School Surakarta. Besides, it also to investigate students' responses toward theme based approach applied in teaching English vocabulary. Data collected from a survey conducted on 24 students of English Club in Nur Hidayah Islamic Elementary School. The technique of collecting the data used observation, interview, and documentary. The data summarized on the usefulness of theme-based approach in teaching English vocabulary. The result of the study showed that the use of theme-based approach is important used by the teacher to get student understanding in learning vocabulary. Furthermore, the teacher should provide various activities maintained student's interest during the lesson.

Keywords: Theme-Based Approach, young learners, integrates, teaching vocabulary, students' responses
\end{abstract}

\section{INTRODUCTION}

Teaching young learners is an issue of the world that still gets attention until now. Young learner as the foundation of education quality in the state, need special attention and approach in English language teaching. Children have a special gift such as golden age and they can learn some competence easily. One of the competences is linguistic competence. According to Chomsky in Clark and Clark (1977: 6), linguistic competence is capacity to use language, and linguistic performance is the application of linguistic competence in speaking or listening. This is special gift for young learner to get these competences easily. Actually, the role of teacher influence children understanding. English language teacher use this occasion to develop linguistic competence of the children.

Indonesian teacher conduct the Theme-based approach to teach refers to Indonesian curriculum 2013. Cameron (2001: 181) state that, theme-based teaching can cover one, two or more lessons a week, or even several weeks. It means that theme-based approach can be integrated in the other 
material. Curtain and Dahlberg (2000) affirm that effective language instruction builds on topics and context that are relevant to learners.

Those activities and topics linked together by the content. This approach makes the children easy to understand the material because all the children become the part in the context of material and the topic link each other.

According to Gordon (2007:44), all normally developing children master the complexity of pronunciation, grammar, and vocabulary of their first language within the first four or five years of their lives. Not only do children learn to use highly sophisticated grammatical forms of their first language, they also develop an impressive vocabulary. It means that children in this context is young learners a new word every waking hour of their day. In the golden age, competences that easy to practice by the children are speaking and listening. This study tries to support those two skills by teaching vocabulary. Rich of vocabularies is important for the children to produce speaking and writing especially. One of the input of vocabulary is listening. The nature of vocabulary from John (2000: 16) says that vocabulary is knowledge of or knowing the meanings of words. It is important for young learners to enrich their vocabulary, in order to make English teaching and learning run well.

Piaget in Hudelson (1991: 256) states that children in primary or elementary school are usually in what is called the concrete operational stage of cognitive development. It means that student learn based on the manipulation and support of the environment. Younger learners respond to language according to what it does or what they can do with it, rather than treating it as an intellectual game or abstract system. Phillips (1993:7) states that teacher should prepare the appropriate teaching media or supporting tool and some activities related to the approach to get student understanding and response during the lesson. The kinds of activities that work well are games and songs with actions, total physical response activities, tasks that involve coloring, cutting, and sticking, simple, repetitive stories, and simple, repetitive speaking activities that have an obvious communication value. (Phillips, 1993:7).

Based on that phenomenon the aims of this study are to find out the use of theme-based approach in teaching English vocabulary for young learners of English club and to investigate students' responses toward theme-based approach applied in teaching English vocabulary.

\section{LITERATURE REVIEW}

Now days some school in Indonesia use theme-based approach for teaching English especially in teaching for young learner. It is the result of 2013 curriculum Indonesia. Cameron (2001) state that theme-based teaching approach suits the way young learners naturally learn. It provides lots of linked activities that allow students who commonly have big enthusiasm to participate actively in the teaching and learning process. Related with that theory, teacher should know the objective in teaching English for young learners. According to Petersen and Hayden, 1961:31) there are nine basic objectives of elementary education.

- The importance of the individual is a basic goal or objective

- Provision for individual differences is a major goal for elementary school teachers.

- The elementary school must provide a type of continuous guidance for all children.

- Teachers and administrators must recognize the importance of considering all phases of the pupil's development. 
- Each child's intellectual development is a paramount goal of the elementary school staff.

- The development of social intelligence is an important goal of elementary education.

- The effective emotional development of each boy and girl is also an important goal for every elementary school staff.

- The previously discussed objectives, if efficiently achieved, result in the realization of the most fundamental objective: that the elementary schools produce effective citizens in our democracy.

There are several studies conducted in different countries, different skill and different characteristic of student. In a study by Bachrudin Musthafa, Teaching English to young learners in Indonesia: essential requirements (2010), the researchers studied some requirements that teachers should know to teach English to young learners. This is a literature study of the theory to teach English for young learners. The result of this research is some components of professional expertise of teachers of English that are crucial implications for teacher training programs. Those training programs are expected to create effective teaches.

Fitria Lathufirdaush, The implementation of theme-based teaching to improve students' speaking skill (2014), this research studied the improvement of the students' speaking skill which covered some aspects; include vocabulary, pronunciation and grammar by classroom action research. This research conducted in one of elementary schools in Bandung. The result of this study shows that the students' speaking skill improved through the implementation of theme-based teaching.

In a research by Jiyoung Jinnie Kim, Principles of content theme based approach in EFL education (2005), studied reliable evidence for the feasibility of Content-Based Instructional in Korean EFL context, theme-based model English language program conducted on a Korean university for intermediate to advanced learners of English. The conclusion of this finding and discussion is there are certain overlapping conditions among such diversity that foster successful learning experiences. This approach to language acquisition provides learner with content and language acquisitions, build learners sense of true maturation and achievement.

Those are previous researches that in line with this research. This research focuses on teaching vocabulary through theme-based approach for teaches young learner in English club and investigates the students' responses toward this approach to teach vocabulary. It includes of reflective response from the students through this approach. Indeed, the touchstone for successful activities in English is the harnessing of activities which are natural to the child's maturational level, those which he pursues normally in his own language. (Broughton, et al, 1980:170).

\section{Ways In Improving Teacher Theme Teaching}

According to Walmsley (1996), there are 10 ways to improve teacher theme when teaching English, as follows:

- Don't try to integrate every subject area into every theme.

- When teach the theme tuck the skills inside it.

- Balance teacher generated and student centered

- Avoid cutesy treatments of themes

- Draw themes from a variety of arenas 
- Make sure the themes are the right size

- Approach yearlong and school wide themes with caution

- Bump up teacher own knowledge about theme which have prepared.

- Teach a theme at least twice and recoup the investment in it.

- Borrow themes idea from others.

\section{METHOD}

This research uses qualitative research, which describes the use of theme-based approach in teaching young learners' vocabulary in English club of Nur Hidayah Elementary Islamic School Surakarta. It uses observation, documentary and interview to the English teacher and the students. Based on the observation done to English teacher and her students, the observations focused on the activities and the atmosphere in the English classroom. It is because the target of observation is to know how the use of theme-based approach in teaching young learners' English vocabulary in English club of Nur Hidayah Elementary Islamic School Surakarta. The theme in September was My Self. The sub-theme in first week of September was Part of Body. The process of teaching English in the use of theme-based approach by teacher were:

- Teacher activity on set induction

In the first activity in teaching English, the teacher started with some songs that they must sing it every day. It related to the greeting, the date and something made fun the class before going to study. The teacher invited the students to sing songs with the movement. The first class was in outdoor the class. The teacher invited students to do the activities for starting the class in the yard in front of this kindergarten.

- Introduction of teaching material

The teacher invited students for coming back to the class. In the class, the teacher did brainstorming to students first. She asked them some of part of body such as "What is this?" by pointing the nose and the students answered it in Bahasa Indonesia because they did not know the name of part of body in English. After doing the brainstorming, she said that the material is about part of body.

- The theme explanation

The teacher showed some papers. Those papers contained the pictures and new English vocabularies of part of body (head, hair, eyes, nose, ear, mouth, hand and foot). She pronounced the vocabularies of each part of body. She asked students to follow her and then she repeated it several time. She often did asking and answering about the vocabularies to students, and sometime she did asking and question by song.

- The material integration

The teacher related the material to the mathematic. The teacher asked students to mention the number 1 to 10 in English, then she asked them. She asked the number of each part of body to students in their bodies. She said "how many eyes do you have?", they answered "two" or she said "how many fingers do you see?", they answered "seven". The students memorized the vocabularies about the number 1 to 10 in English.

- Singing songs

The teacher asked the students to sing together. The title was my body. The song consists of the new vocabularies about part of body in English and Bahasa Indonesia. Based on the interview, the teacher made the song by her own based on the theme. The song was bilinguals (mother tongue and target language) because it made students faster and easier in understanding and memorizing the new English vocabularies. The teacher taught them vocabularies by singing 
a song with gesture. When they said "ear", they must touched their ears. The teacher repeated the song several time until the students were getting memorize it.

- Doing games

The teacher invited the students to do the games. The games were introducing the body and touching friend. Before doing the games, the teacher explained the roles of the games to make students easy to understand the game. The first game was introducing the body. The teacher called one student to move forward. The teacher showed some pictures of part of body and asked the chosen student each of pictures. The student who had chosen must answer it in English. The teacher said "What is this?" or "Where is the eyes?", the chosen student answered "eyes" or pointing the picture of eyes. The special need students also followed the game.

The second game was touching friend. The teacher asked the students to make two big circles, the boys and the girls. The teacher asked them to touch their friends that were beside them. When the teacher called "touch your friend' nose!", the students touched their friend' nose that were beside them.

- Giving the tasks

The teacher gave the tasks to the students. The first task was counting and it was relating to the material that already studied. The teacher gave the printable task to students. In the printable task, there were five pictures of part of body. It was the number of eyes, noses, ears, moths and hands. The students count the picture and write the sum of those pictures. The teacher also asked them to coloring the pictures of part of body after they finished counting.

The second task was writing. The teacher distributed students' books. In the book, the teacher wrote the word Eyes = Mata. She asked the students to write it in their books. The teacher asked the students to write ten lines. For special need students, the teacher wrote the word by the dotted letters in their book, so the students must connected or bolded it.

- The evaluation and appeasement

Before the end of class, the teacher asked students to remember again the new vocabularies about part of body that they learned. They asked them some new vocabularies, and sometimes she asked them by song. In the end, the teacher also asked them to sing a song of part of body together.

\section{FINDINGS AND DISCUSSION}

The themes used in English club of Nur Hidayah elementary Islamic school Surakarta based on school curriculum from Religious Ministry. The themes appropriated to the age of students as young learners. Those themes are started with the theme around the students like their self, their family and their school, then, continued by others like the country, animal and plant. It is good in choosing the themes for young learners. With theme-based approach, the teacher can organize her class by her own. English teacher can enrich every theme with fun activities and appropriate media for students.

\section{Teaching Activities in English Club of Nur Hidayah Elementary Islamic School Surakarta} In the activities, theme-based approach gives the teacher a freedom to make her own class. The teacher can organize her class by her own. Based on observation in English Club, the teacher give various activities every week for students in their English club, but the activities appropriated to the age of students as young learners. The various activities give positive affect for students. It makes students are excited to the English lesson and they fell happy when they follows the class. The students express their enthusiasm in all activities that the teacher gives. 


\section{The Integration in the Use of Theme-Based Approach}

The integration is one way to recognize theme-based approach. English teacher in Nur Hidayah elementary Islamic school integrates English subject to others, such as mathematics, science and art. The integration gives the positive effect to students. It makes the students can study some lessons in one time and they can implement one lesson to other lesson. For the teacher, it makes her easier to teach English and other lesson in one time. She can relate English to other lesson and make fun activities about lessons for children by her own.

\section{Techniques in the Use of Theme-Based Approach}

The using of appropriate technique needed in teaching young learners. The English teachers use some techniques through the use of theme-based approach. Those are in line with the age of the students as young learners. The teacher uses some techniques in her class, such as singing song, doing games, telling story, writing, coloring and drawing, matching, crafting, counting, question and answer, and doing drills. The teacher chooses the appropriate techniques and it adjusts the themes and age of students. She uses the technique that can espouse teaching process. Every technique has own advantages for students and those techniques make students easier in receive the lesson.

\section{Media in the Use of Theme-Based Approach}

The media needed in the process of teaching and learning. In young learners' class, the media is necessary because it serves as a tool to attract the attention and grow the interest in children participates in the learning process. The teacher uses the media in her class, such as pictures, coloring papers, puppets, printable tasks, video, laptop and projector. She uses the media that can espouse teaching process. Every media has own advantages and those media help teacher in teaching process and students in learning process.

\section{Students' Responses toward the Theme-Based Approach}

Students give positive responses toward the use of theme-based approach. The most students state that the use of theme based approach in the teaching and learning process helps them to comprehend the lesson better. They also enjoy the lesson in the use of theme-based approach. Students also show strong interest with high enthusiasm in teaching and learning English process. As conclusion, for these three reasons, the use of theme-based approach is good and students gives positive responses about it.

\section{CONCLUSION AND SUGGESTION}

The use of theme-based approach in teaching vocabulary to young learners is good. The English teacher uses all actions in (1) themes, (2) activities (3) integrations, (3) techniques, and (4) media. All activities are very good, the teacher adjusts the activities to the themes and students' ages. The integration of lesson also be an address to know about theme-based approach. The integration were (a) English and mathematics, (b) English and science and (c) English and art. In the use of theme-based approach, it used some techniques. The techniques were (a) song and movement, (b) games, (c) story-telling, (d) writing, (e) coloring and drawing, (f) matching, (g) crafting, (h) counting, (i) question and answer, and (j) drills. It also was used some media. The media were (a) pictures, (b) colored paper, (c) puppet, (d) printable task, and (e) video, laptop and projector. 
Students give positive responses toward the use of theme-based approach. The first reason is they comprehend the lesson better. That statement was proven by students' ability to recall the theme and material about vocabulary they learned in previous meeting. The second reason is they enjoyed the lesson. From some students, the reasons are because it was presented through various activities so that the lesson was not boring, the activities were interesting so that it attracted students to follow the lesson more, and the use of pictures, games and other media make the lesson more satisfying. The third reason is the students expressed their enthusiasm in teaching process.

The teacher who wants to use theme-based approach in their classroom, it is important to set a theme that suits with children ages. It is suggested that the teacher chooses the themes that are familiar with the students. Choosing the themes that are familiar with them can raise students' motivation and their interest in learning English. Furthermore, the teacher should provide various activities which can maintain students' interest during the lesson. It is important since the students might be bored by the materials that only focus on a certain theme. The Students of kindergarten who learn using theme-based approach, hopefully, they can enjoy the activities in teaching English process. Concurrently, the objective of giving English to children can be achieved.

\section{REFERENCES}

Allen, V.F. (1983). Techniques in Teaching Vocabulary. USA: Oxford University Press.

Annual Editions, Early Childhood Education. (1998). USA: Mc Graw-Hill Companies.

Cameron, Lynne, (2001). Teaching Language to Young Learner, United Kingdom: Cambridge University Press.

Clark, Herbert H. and Clark, Eve V. (1977). Psychology and Language. New York: Harcourt.

Curtain, H., \& DALBERG, C. (2000). Planning for Success: Common Putfalls in the Planning of Early Foreign Language Programs. ED447726. Washington DC: ERIC Clearing House on Languages and Linguistics.

Gordon, T. (2007). Teaching Young Children a Second Language. USA: Praeger Publisher.

Hayden, V.D., \& Petersen, D.G. (1961). Teaching and Learning in the Elementary School. USA: Appleton-Century-Crofts, Inc.

Hudelson, S. (1991). EFL Teaching and Children: A Topic-Based Approach (The

English Teaching Forum). Arizona State University, USA.

Kamil, L. M., \& Hiebert, E.H. (2005). Teaching and Learning Vocabulary (Bringing Research to Practice). London: Lawrence Erlbaum Associates Publishers.

Kim, JiyoungJinnie, (2005). Principles of Content-Theme-Based Approach in EFL Education, Journal of Education Development, 21(2), 141-162.

Lathufirdaush, F. (2014). The Implementation of Theme-Based Teaching to Improve Students' Speaking Skill (A Classroom Action Research at One of Elementary Schools in Bandung), Journal of English and Education, 2(1), 9-16.

Musthafa, B. (2010). Teaching English to Young Learners in Indonesia:Essential Requirements, Journal of Educationist, 4 (2).

Phillips, S. (1993). Young Learners. USA: Oxford University Press.

Sukarno, (2008).Teaching English to Young Learners and Factors to Consider in Designing the Materials. Journal of Economic and Education, 5 (1). 